\title{
The Role of Vitamin E in Immunity
}

\author{
Ga Young Lee ${ }^{1,2}$ and Sung Nim Han ${ }^{1,2, *(1)}$ \\ 1 Department of Food and Nutrition, College of Human Ecology, Seoul National University, \\ Seoul 08826, Korea; lgykiki90@snu.ac.kr \\ 2 Research Institute of Human Ecology, Seoul National University, Seoul 08826, Korea \\ * Correspondence: snhan@snu.ac.kr; Tel.: +82-2-880-6836
}

Received: 30 September 2018; Accepted: 29 October 2018; Published: 1 November 2018

\begin{abstract}
Vitamin E is a fat-soluble antioxidant that can protect the polyunsaturated fatty acids (PUFAs) in the membrane from oxidation, regulate the production of reactive oxygen species (ROS) and reactive nitrogen species (RNS), and modulate signal transduction. Immunomodulatory effects of vitamin E have been observed in animal and human models under normal and disease conditions. With advances in understating of the development, function, and regulation of dendritic cells (DCs), macrophages, natural killer (NK) cells, T cells, and B cells, recent studies have focused on vitamin E's effects on specific immune cells. This review will summarize the immunological changes observed with vitamin E intervention in animals and humans, and then describe the cell-specific effects of vitamin $\mathrm{E}$ in order to understand the mechanisms of immunomodulation and implications of vitamin E for immunological diseases.
\end{abstract}

Keywords: vitamin E; macrophages; T cells; dendritic cells; immunomodulation; infection

\section{Vitamin E: Definition, Structure, Sources, and Functions}

\subsection{Definition and Structure}

Vitamin $E$ is the collective term for four tocopherols $(\alpha-, \beta-, \gamma-$, and $\delta$-tocopherols) and four tocotrienols $(\alpha-, \beta-, \gamma-$, and $\delta$-tocotrienols) found in food. These forms have antioxidant activities, but cannot be interconverted, and only $\alpha$-tocopherol meets the human vitamin E requirement [1]. Tocopherols have a chromanol ring and a phytyl tail, while tocotrienols have a chromanol ring and an unsaturated tail. The $\alpha-, \beta-, \gamma-$, and $\delta$ - forms differ in the number and position of methyl groups on the chromanol structure. Natural tocopherols have only $R R R$ stereochemistry, but synthetic tocopherols are mixtures of eight stereoisomers (RRR-, $R S R-$-, RRS-, $R S S_{-}, S R R-$, SSR-, $S R S-$-, $\left.S S S_{-}\right)$, because there are three asymmetric carbon atoms $\left(2 R, 4^{\prime} R, 8^{\prime} R\right)$ present in the phytyl tail. The structures of tocopherols and tocotrienols are shown in Figure 1. 


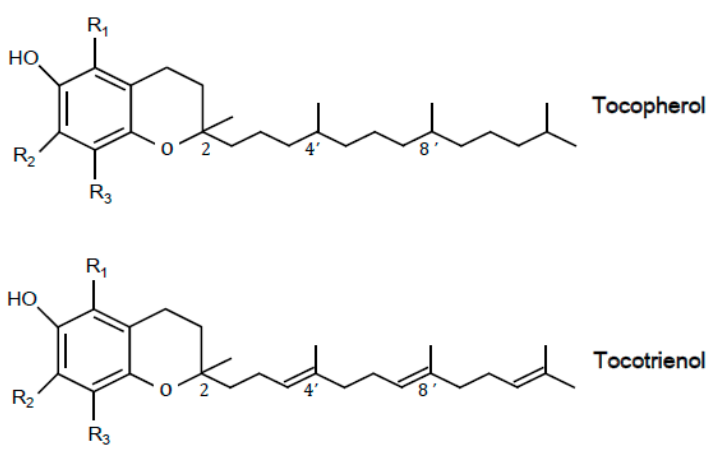

\begin{tabular}{|c|c|c|c|}
\hline $\mathbf{R}_{1}$ & $\mathrm{R}_{2}$ & $\mathrm{R}_{3}$ & \\
\hline $\mathrm{CH}_{3}$ & $\mathrm{CH}_{3}$ & $\mathrm{CH}_{3}$ & $\alpha-$ \\
$\mathrm{CH}_{3}$ & $\mathrm{H}$ & $\mathrm{CH}_{3}$ & $\beta-$ \\
$\mathrm{H}$ & $\mathrm{CH}_{3}$ & $\mathrm{CH}_{3}$ & $\gamma-$ \\
$\mathrm{H}$ & $\mathrm{H}$ & $\mathrm{CH}_{3}$ & $\delta-$ \\
\hline
\end{tabular}

Figure 1. The structures of tocopherol and tocotrienols.

\subsection{Sources}

The major dietary sources of vitamin $\mathrm{E}$ are vegetable oils. Nuts are good sources of vitamin $\mathrm{E}$ as well [2]. Soybean, sunflower, corn, walnut, cottonseed, palm, and wheat germ oils contain relatively higher amounts (more than approximately $50 \mathrm{mg}$ vitamin E/100 $\mathrm{g}$ oil) of vitamin $\mathrm{E}$ than other oils. The proportions of $\alpha-, \beta-, \gamma-$, and $\delta$-tocopherols vary depending on the oil type. Safflower and sunflower oils are high in $\alpha$-tocopherol, soybean and corn oils contain mainly $\gamma$-tocopherol, and cottonseed oil contains similar proportions of $\alpha$ - and $\gamma$-tocopherols. Therefore, the types of oils consumed through the diet affect the dietary intake levels of $\alpha$-tocopherol. Vitamin E supplements are quite popular and contribute considerably to vitamin E intake among some populations. Either natural or synthetic forms of $\alpha$-tocopherol are used as supplements.

Despite the relatively higher intake of $\gamma$-tocopherol from the diet than $\alpha$-tocopherol, $\alpha$-tocopherol is the major form of vitamin $\mathrm{E}$ in the circulation because $\alpha$-tocopherol transfer protein $(\alpha$-TTP) has the preferential binding affinity for $\alpha$-tocopherol. $\alpha$-TTP is involved in the transfer of $\alpha$-tocopherol to the plasma membrane [1].

\subsection{Functions}

Vitamin $\mathrm{E}$ is a major fat-soluble antioxidant that scavenges peroxyl radicals and terminates the oxidation of polyunsaturated fatty acids (PUFAs). In the presence of vitamin E, peroxyl radicals react with $\alpha$-tocopherol instead of lipid hydroperoxide, the chain reaction of peroxyl radical production is stopped, and further oxidation of PUFAs in the membrane is prevented [1]. Tocopheroxyl radicals-produced from $\alpha$-tocopherol and peroxyl radicals-are reduced by vitamin $C$ or glutathione, form tocopherol dimers, undergo further oxidation, or act as prooxidants. The antioxidant activity of vitamin $\mathrm{E}$ may be responsible for the regulation of several enzymes involved in signal transduction because the activity of signaling enzymes is regulated by the redox state.

Vitamin E inhibits protein kinase C (PKC) activity by increasing PKC- $\alpha$ dephosphorylation through the activation of protein phosphatase 2A. The inhibition of PKC by vitamin $\mathrm{E}$ has been reported in various cells, and consequently, the inhibition of platelet aggregation; reduced proliferation of monocytes, macrophages, neutrophils, and vascular smooth muscle cells; and decreased superoxide production in neutrophils and macrophages have been observed [3,4].

Vitamin E may directly bind to the enzymes involved in the generation of lipid mediators or to the transport proteins involved in signal transduction. Vitamin E may affect the membrane protein 
interaction and translocation of the enzymes to the plasma membrane and therefore change the activity of signal transduction enzymes [4].

\section{Modulation of Immune Responses and Infectious Diseases by Vitamin E Supplementation}

\subsection{Immune Responses in Animals}

Dietary interventions of vitamin $\mathrm{E}$ at supplemental levels have been shown to enhance cell-mediated and humoral immune responses in various species of animals. Increased lymphocyte proliferation, immunoglobulin levels, antibody responses, natural killer (NK) cell activity, and interleukin (IL)-2 production have been reported with vitamin E supplementation (Table 1).

\subsection{Immune Responses in Humans}

In humans, many intervention studies have reported increased lymphocyte proliferation in response to mitogenic stimulation, enhanced delayed type hypersensitivity (DTH) response, increased IL-2 production, and decreased IL-6 production with vitamin E supplementation above the recommended levels. However, some studies showed no difference or decreased lymphocyte proliferation responses and decreased chemiluminescence. (Table 2). Differences in dose of vitamin E supplementation used, magnitude of vitamin E level changes with supplementation, age of subjects, and methodology (determination of antibody levels with or without specific vaccination) might have contributed to the different results observed.

\subsection{Infectious Diseases in Animals}

The immunostimulatory effect of vitamin $\mathrm{E}$ has resulted in enhanced resistance against several pathogens. Animal studies in which infectious disease models were used to test the effects of vitamin E supplementation are listed in Table 3.

The mechanisms involved with protection against infectious agents were increased macrophage activity and antibody $(\mathrm{Ab})$ production for D. pneumoniae type 1 [5], and higher NK activity and Th1 response for influenza virus [6,7].

\subsection{Infectious Diseases in Humans}

In humans, the effects of vitamin $\mathrm{E}$ on the natural incidence of infectious diseases have been determined in several studies (Table 4). Many studies provided evidence that the immunostimulatory effects of vitamin E confer improved resistance to infections. However, the magnitudes of the effects were rather small, and in some studies, positive effects were only observed in subgroups of subjects. 
Table 1. Modulation of immune responses by vitamin E in animal models.

\begin{tabular}{|c|c|c|c|c|}
\hline Species & Dosage and Duration & Form of Vitamin E Used & Results & References \\
\hline $\begin{array}{c}\text { Chicks, female broiler ( } n=6 / \text { group, } \\
6 \text { replicate) }\end{array}$ & $100 \mathrm{mg} / \mathrm{kg}$ diet for 21 days & DL- $\alpha$-tocopheryl acetate & $\begin{array}{c}\uparrow \text { Plasma IgM levels at day } 21 \\
\leftrightarrow \text { Splenic expressions of TNF- } \alpha \text {, IFN- } \gamma \text {, IL-2, IL-10 }\end{array}$ & Dalia et al. 2018 [8] \\
\hline Pregnant cows ( $n=24$ /group) & $\begin{array}{l}250 \mathrm{IU} / \text { day from day } 107 \text { of } \\
\text { gestation to day } 21 \text { of lactation }\end{array}$ & NA & $\uparrow \operatorname{IgG}$ and IgA concentration in sow plasma & Wang et al. 2017 [9] \\
\hline $\begin{array}{l}\text { Domestic cats ( } 39 \text { castrated male and } \\
33 \text { intact female) }(n=8 / \text { group })\end{array}$ & $225,450 \mathrm{mg} / \mathrm{kg}$ diet for 28 days & $\alpha$-tocopherol & $\uparrow$ Lymphocyte proliferation (ConA, PHA) & O' Brien et al. 2015 [10] \\
\hline Young and old mice ( $n=11-13 /$ group) & $500 \mathrm{mg} / \mathrm{kg}$ diet for 6 weeks & DL- $\alpha$-tocotrienol & $\begin{array}{c}\uparrow \text { Lymphocyte proliferation in old (ConA, PHA) } \\
\uparrow \text { IL- } 1 \beta \text { production in young }\end{array}$ & Ren et al. 2010 [11] \\
\hline Young rats ( $n=6 /$ group) & $\begin{array}{l}50,200 \mathrm{mg} / \mathrm{kg} \text { diet for } \\
8-10 \text { weeks }\end{array}$ & & $\uparrow$ Lymphocyte proliferation (ConA, LPS) & Bendich et al. 1986 [12] \\
\hline Old mice ( $n=10 /$ group) & $500 \mathrm{mg} / \mathrm{kg}$ diet for 6 weeks & DL- $\alpha$-tocopheryl acetate & $\begin{array}{c}\uparrow \text { Lymphocyte proliferation (ConA, LPS) } \\
\uparrow \mathrm{DTH} \text { response } \\
\uparrow \mathrm{IL}-2 \text { production } \\
\downarrow \mathrm{PGE}_{2} \text { production }\end{array}$ & Meydani et al. 1986 [13] \\
\hline Young and old mice ( $n=5 /$ group) & $500 \mathrm{IU}(500 \mathrm{mg})$ for 9 weeks & DL- $\alpha$-tocopherol acetate & $\begin{array}{l}\uparrow \text { Lymphocyte proliferation (ConA) in young } \\
\leftrightarrow \text { Lymphocyte proliferation (ConA) in old } \\
\uparrow I F N-\gamma \text { in young under restraint stress }\end{array}$ & Wakikawa et al. 1999 [14] \\
\hline Young rats ( $n=10 /$ group) & $\begin{array}{l}50,100,250,500,2500 \mathrm{mg} / \mathrm{kg} \\
\text { diet for } 7 \text { days }\end{array}$ & DL- $\alpha$-tocopheryl acetate & $\begin{array}{c}\uparrow \text { Lymphocyte proliferation ( }>100 \mathrm{mg} / \mathrm{kg} \text { diet, } \\
\text { ConA) }(>250 \mathrm{mg} / \mathrm{kg} \text { diet, LPS) } \\
\uparrow \mathrm{NK} \text { activity }(>250 \mathrm{mg} / \mathrm{kg} \text { diet })\end{array}$ & Moriguchi et al. 1990 [15] \\
\hline Old rats ( $n=5 /$ group) & $585 \mathrm{mg} / \mathrm{kg}$ diet for 12 months & DL- $\alpha$-tocopheryl nicotinate & $\begin{array}{c}\uparrow \text { Lymphocyte proliferation (ConA, PHA) } \\
\uparrow I L-2 \text { production }\end{array}$ & Sakai S \& Moriguchi 1997 [16] \\
\hline Young calves ( $n=8 /$ group) & $\begin{array}{l}125,250,500 \mathrm{IU}(125,250 \\
500 \mathrm{mg}) / \text { day for } 24 \text { weeks }\end{array}$ & DL- $\alpha$-tocopheryl acetate & $\begin{array}{l}\uparrow \text { Lymphocyte proliferation (PHA, ConA, } \\
\text { pokeweed mitogen) } \\
\text { Antibovine herpesvirus Ab titer to booster in } \\
125 \mathrm{IU} / \text { day group }\end{array}$ & Reddy et al. 1987 [17] \\
\hline Young mice ( $n=8 /$ group) & $200 \mathrm{mg} / \mathrm{kg}$ diet for 6-12 weeks & $\alpha$-tocopheryl acetate & $\begin{array}{c}\uparrow A b \text { response } \\
\uparrow \text { Helper T cell activity }\end{array}$ & Tanake et al. 1979 [18] \\
\hline Mice ( $n=10 /$ group) & $500 \mathrm{mg} / \mathrm{kg}$ diet for 6 months & $\begin{array}{l}\alpha \text {-tocopherol acetate (Tekland, } \\
\text { Madison, WI) }\end{array}$ & $\begin{array}{c}\downarrow \text { IL-6 and PGEs (unstimulated) production by } \\
\text { macrophages } \\
\downarrow \text { Nitric oxide production (LPS) by macrophages }\end{array}$ & Beharka et al. 2000 [19] \\
\hline
\end{tabular}

$\mathrm{Ab}$, antibody; ConA, concanavalin $\mathrm{A}$; IFN- $\gamma$, interferon- $\gamma$; LPS, lipopolysaccharide; $\mathrm{PGE}_{2}$, prostaglandin $\mathrm{E}_{2} ; \mathrm{PHA}$, phytohemagglutinin; TNF, Tumor necrosis factor. 
Table 2. Modulation of immune responses by vitamin E in humans.

\begin{tabular}{|c|c|c|c|c|c|}
\hline Subjects & Age & Amount and Duration of Supplementation & Form of Vitamin E Used & Effects on Immune Function & References \\
\hline $\begin{array}{l}\text { Young }(n=5) \text { and senior } \\
\text { athletes }(n=5)\end{array}$ & $18-25,35-57$ & $\begin{array}{c}4.6 \pm 0.3 \mathrm{mg} / 100 \mathrm{~mL} \text { of vitamin E-enriched } \\
\text { beverage } 5 \text { days } / \text { week for } 5 \text { weeks }\end{array}$ & $\alpha$-tocopherol acetate & $\uparrow 15 \mathrm{LOX} 2, \mathrm{TNF}-\alpha$ expression & Capo et al. 2016 [20] \\
\hline \multirow{2}{*}{ Healthy women $(n=108)$} & \multirow{2}{*}{$18-25$} & \multirow{2}{*}{$400 \mathrm{mg} \mathrm{TRF} /$ day for 56 days } & $\begin{array}{l}\text { D- } \alpha \text {-tocotrienol } \\
\text { D- } \gamma \text {-tocotrienol }\end{array}$ & $\uparrow \mathrm{IL}-4$ (TT vaccine), IFN- $\gamma$ (ConA) & \multirow{2}{*}{ Mahalingam et al. 2011 [21] } \\
\hline & & & $\begin{array}{l}\text { D- } \delta \text {-tocotrienol } \\
\text { D- } \alpha \text {-tocopherol }\end{array}$ & $\downarrow$ IL-6 (LPS) & \\
\hline $\begin{array}{l}\text { Healthy men and women } \\
\qquad(n=19,34)\end{array}$ & $20-50$ & $200 \mathrm{mg} /$ day for 56 days & $\alpha$-tocopherol & $\leftrightarrow \mathrm{IL}-4, \mathrm{IFN}-\gamma$ production $(\mathrm{ConA})$ & Radhakrishnan et al. 2009 [22] \\
\hline $\begin{array}{l}\text { Adult males and young boys } \\
\qquad(n=18)\end{array}$ & $25-30,13-18$ & $300 \mathrm{mg} /$ day for 3 weeks & DL- $\alpha$-tocopheryl acetate & $\begin{array}{c}\downarrow \text { Lymphocyte proliferation (PHA) } \\
\leftrightarrow \text { DTH } \\
\downarrow \text { Bactericidal activity }\end{array}$ & Prasad 1980 [23] \\
\hline $\begin{array}{l}\text { Institutionalized adult males } \\
\text { and females }(n=103)\end{array}$ & 24-104 & $200,400 \mathrm{mg} /$ day for 6 months & $\alpha$-tocopherol acetate & $\leftrightarrow \mathrm{Ab}$ development to influenza virus & Harman and Miller 1986 [24] \\
\hline $\begin{array}{l}\text { Healthy elderly males and } \\
\text { females }(n=32)\end{array}$ & $\geq 60$ & $800 \mathrm{mg} /$ day for 30 days & DL- $\alpha$-tocopheryl acetate & $\begin{array}{c}\text { ^Lymphocyte proliferation (ConA) } \\
\uparrow \mathrm{DTH} \\
\uparrow \mathrm{IL}-2 \text { production (ConA) } \\
\downarrow \mathrm{PGE}_{2} \text { production (PHA) } \\
\end{array}$ & Meydani et al. 1990 [25] \\
\hline $\begin{array}{l}\text { Eldery males and females } \\
(n=74)\end{array}$ & $\geq 65$ & $100 \mathrm{mg} /$ day for 3 months & DL- $\alpha$-tocopheryl acetate & $\begin{array}{c}\leftrightarrow \text { Lymphocyte proliferation (ConA, PHA) } \\
\leftrightarrow \text { IgG, IgA levels }\end{array}$ & De Waart et al. 1997 [26] \\
\hline $\begin{array}{l}\text { Healthy elderly males and } \\
\text { females }(n=88)\end{array}$ & $\geq 65$ & $60,200,800 \mathrm{mg} /$ day for 235 days & DL- $\alpha$-tocopherol & $\uparrow$ DTH and antibody titer to hepatitis B with $200,800 \mathrm{mg}$ & Meydani et al. 1997 [27] \\
\hline $\begin{array}{l}\text { Healthy elderly males and } \\
\text { females }(n=161)\end{array}$ & $65-80$ & $50,100 \mathrm{mg} /$ day for 6 months & DL- $\alpha$-tocopheryl acetate & $\begin{array}{l}\uparrow \text { No. of positive DTH reaction with } 100 \mathrm{mg} \\
\uparrow \mathrm{dDiameter} \text { of induration of DTH reaction in a } \\
\text { subgroup supplemented with } 100 \mathrm{mg} \\
\leftrightarrow \text { IL-2 production } \\
\downarrow \downarrow \text { IFN- } \gamma \text { production }\end{array}$ & Pallast et al. 1999 [28] \\
\hline $\begin{array}{l}\text { Healthy young adults }(n=31) \\
\text { and premature infants }(n=10)\end{array}$ & $24-31$ & $\begin{array}{l}600 \mathrm{mg} / \text { day for } 3 \text { months } 40 \mathrm{mg} / \mathrm{kg} \text { body } \\
\text { weight for 8-14 days }\end{array}$ & & $\downarrow$ Chemiluminescence & Okano et al. 1990 [29] \\
\hline Cigarette smoker $(n=60)$ & $33 \pm 4$ & $900 \mathrm{IU} /$ day for 6 weeks & & $\downarrow$ Chemiluminescence & Richards et al. 1990 [30] \\
\hline Healthy males $(n=40)$ & $24-57$ & $200 \mathrm{mg} /$ day for 4 months & all-rac- $\alpha$-tocopherol & $\begin{array}{l}\text { Prevented fish-oil-induced suppression of ConA } \\
\text { mitogenesis }\end{array}$ & Kramer et al. 1991 [31] \\
\hline Healthy elderly $(n=40)$ & $>65$ & 100,200 , or $400 \mathrm{mg} /$ day for 3 months & DL- $\alpha$-tocopherol & $\begin{array}{l}\uparrow \mathrm{DTH} \text { (maximal diameter) in 100, 200, } 400 \mathrm{mg} \text { groups } \\
\uparrow \text { Lymphocyte proliferation (ConA) in } 200 \mathrm{mg} \text { group }\end{array}$ & Wu et al. 2006 [32] \\
\hline $\begin{array}{l}\text { Sedentary young and elderly } \\
\text { males }(n=21)\end{array}$ & $22-29,55-74$ & $800 \mathrm{IU}(727 \mathrm{mg}) /$ day for 48 days & DL- $\alpha$-tocopherol & $\begin{array}{c}\downarrow \text { IL-6 secretion } \\
\downarrow \text { Exercise-enhanced IL-1 } \beta \text { secretion }\end{array}$ & Cannon et al. 1991 [33] \\
\hline
\end{tabular}

ConA, concanavalin A; DTH, delayed type hypersensitivity; IFN- $\gamma$, interferon- $\gamma$; 15LOX2, 15-lipoxygenase-2; $\mathrm{PGE}_{2}$, prostaglandin $\mathrm{E}_{2}$; PHA, phytohemagglutinin; TRF, tocotrienol-rich

fraction; TT vaccine, tetanous toxoid vaccine. 
Table 3. Effects of vitamin E supplementation on infectious diseases in animal models.

\begin{tabular}{|c|c|c|c|c|c|c|}
\hline Subjects & Age & $\begin{array}{l}\text { Dose and Duration of } \\
\text { Supplementation }\end{array}$ & $\begin{array}{c}\text { Form of Vitamin E } \\
\text { Used }\end{array}$ & $\begin{array}{l}\text { Infection Organism and } \\
\text { Route of Infection }\end{array}$ & $\begin{array}{l}\text { Results: Effects of Vitamin E } \\
\text { Supplementation }\end{array}$ & References \\
\hline $\begin{array}{l}\text { Mice BALB/c } \\
(n=3-6 / \text { group })\end{array}$ & 6 months & $\begin{array}{l}100 \mathrm{mg} / \mathrm{kg} \text { for } 8 \text { days before } \\
\text { MRSA-challenge }\end{array}$ & $\delta-, \gamma$-Tocotrienol & $\begin{array}{l}\text { MRSA, inoculated onto } \\
\text { superficial surgical wounds }\end{array}$ & $\begin{array}{c}\text { Higher NK cytotoxicity } \\
\text { Higher IL-24 mRNA expression levels }\end{array}$ & Pierpaoli et al. 2017 [34] \\
\hline $\begin{array}{l}\text { Young and aged male } \\
\text { mice C57BL/6 } \\
(n=6 / \text { group })\end{array}$ & $2,22-26$ months & $\begin{array}{l}500 \mathrm{mg} / \mathrm{kg} \text { for } 4 \text { weeks prior to } \\
\text { infection }\end{array}$ & $\begin{array}{l}\text { D- } \alpha \text {-tocopheryl } \\
\text { acetate }\end{array}$ & $\begin{array}{l}\text { Streptococcus pneumoniae, } \\
\text { intra-tracheally injected }\end{array}$ & $\begin{array}{l}\text { 1000-fold fewer bacteria in their lung } \\
\text { Age-associated higher production of } \\
\text { proinflammatory cytokines (TNF-, IL-6) } \\
\text { were reduced } \\
\text { 3-fold reduction in the number of PMNs }\end{array}$ & Bou Ghanem et al. 2015 [35] \\
\hline $\begin{array}{l}\text { Worm-free lambs } \\
(n=10 / \text { group })\end{array}$ & 28-32 weeks & $\begin{array}{l}5.3 \mathrm{IU}(3.56 \mathrm{mg}) / \mathrm{kg} \text { BW for } \\
12 \text { weeks }\end{array}$ & D- $\alpha$-tocopherol & $\begin{array}{l}\text { H. contortus L3 larvae, route } \\
\text { NA }\end{array}$ & $\begin{array}{l}\text { No difference in serum IgG or peripheral } \\
\text { mRNA expression of IL-4 or IFN- } \gamma \\
\text { Lower PCV, FEC, and worm burden }\end{array}$ & De Wolf et al. 2014 [36] \\
\hline $\begin{array}{l}\text { Male mice BALB } / \mathrm{c} \\
(n=6-7 / \text { group })\end{array}$ & At weaning & $\begin{array}{l}\text { Deficient, Adequate } \\
(38.4 \mathrm{mg} / \mathrm{kg} \text { diet), or } \\
\text { Supplemented ( } 384 \mathrm{mg} / \mathrm{kg} \\
\text { diet) for } 4 \text { weeks }\end{array}$ & $\begin{array}{l}\text { DL- } \alpha \text {-tocopheryl } \\
\text { acetate }\end{array}$ & HSV-1, intranasally & $\begin{array}{l}\text { Higher viral titre and IL } \beta, \text { TNF- } \alpha, \\
\text { RANTES in the brain with E deficiency } \\
\text { No difference in expressions of IL- } 6, \\
\text { TNF } \alpha, \text { IL- } 1 \beta \text {, and IL- } 10 \text { between } \\
\text { adequate and supplemented }\end{array}$ & Sheridan \& Beck. 2008 [37] \\
\hline $\begin{array}{c}\text { Mice C57BL } \\
(n=6-9 / \text { group })\end{array}$ & 22 months & $500 \mathrm{mg} / \mathrm{kg}$ diet for 8 weeks & $\begin{array}{l}\text { DL- } \alpha \text {-tocopherol } \\
\text { acetate }\end{array}$ & $\begin{array}{l}\text { Influenza by nasal } \\
\text { inoculation }\end{array}$ & $\begin{array}{c}\text { Lower viral titer } \\
\text { Higher IL-2 and IFN- } \gamma \text { production }\end{array}$ & Han et al. 2000 [6] \\
\hline $\begin{array}{l}\text { Mice, C57BL } / 6 \\
\quad(n=4-9)\end{array}$ & 22 months & $500 \mathrm{mg} / \mathrm{kg}$ diet for 6 weeks & $\begin{array}{l}\text { DL- } \alpha \text {-tocopherol } \\
\text { acetate }\end{array}$ & $\begin{array}{c}\text { Influenza } \mathrm{A} / \mathrm{PC} / 1 / 73 \\
\text { (H3N2) by nasal inoculation }\end{array}$ & Lower viral titre & Hayek et al. 1997 [7] \\
\hline Mice, C57BL/6 $(n=6)$ & 5 weeks & $\begin{array}{l}160 \mathrm{IU} / \mathrm{L} \text { liquid diet for } 4,8,12, \\
16 \text { weeks }\end{array}$ & $\begin{array}{l}\text { all-rac- } \alpha \text {-tocopheryl } \\
\text { acetate }\end{array}$ & $\begin{array}{l}\text { Murine LP-BM5 leukaemia } \\
\text { retrovirus by IP injection }\end{array}$ & $\begin{array}{l}\text { Restored IL-2 and IFN- } \gamma \text { production by } \\
\text { splenocytes following infection }\end{array}$ & Wang et al. 1994 [38] \\
\hline $\begin{array}{l}\text { Calves, Holstein } \\
\qquad(n=7)\end{array}$ & $1 \mathrm{~d}$ & $\begin{array}{l}1400 \text { or } 2800 \mathrm{mg} \text { orally once per } \\
\text { week, } 1400 \mathrm{mg} \text { injection once } \\
\text { per week for } 12 \text { weeks }\end{array}$ & $\begin{array}{l}\text { DL- } \alpha \text {-tocopheryl } \\
\text { acetate }\end{array}$ & $\begin{array}{l}\text { Bovine rhinotracheitis virus, } \\
\text { in vitro }\end{array}$ & $\begin{array}{l}\text { Serum from vitamin E-supplemented } \\
\text { calves inhibited the replication of bovine } \\
\text { rhinotracheitis virus in vitro }\end{array}$ & Reddy et al. 1986 [39] \\
\hline $\begin{array}{l}\text { Mice, Swiss Webster } \\
\qquad(n=10)\end{array}$ & 4 weeks & $180 \mathrm{mg} / \mathrm{kg}$ diet for 4 weeks & $\begin{array}{l}\text { DL- } \alpha \text {-tocopheryl } \\
\text { acetate }\end{array}$ & $\begin{array}{l}\text { Diplococcus pneumoniae type I } \\
\text { by IP injection }\end{array}$ & Higher survival & Heinzerling et al. 1974a [5] \\
\hline $\begin{array}{l}\text { Mice, BALB/C } \\
\quad(n=25)\end{array}$ & NA & $\begin{array}{c}25 \text { or } 250 \mathrm{mg} / \mathrm{kg} \text { bw orally for } \\
4 \text { days, starting } 2 \text { days before } \\
\text { burn injury }\end{array}$ & $\begin{array}{l}\text { DL- } \alpha \text {-tocopheryl } \\
\text { acetate }\end{array}$ & $\begin{array}{c}\text { Pseudomonas aeruginosa, } \\
\text { subeschar injection to burned } \\
\text { mice }\end{array}$ & Lower mortality rate & Fang et al. 1990 [40] \\
\hline Mice, BALB/C (NA) & 3 weeks & $\begin{array}{l}4000 \mathrm{mg} / \mathrm{kg} \text { diet for } 2,4, \text { or } \\
14 \text { weeks }\end{array}$ & $\begin{array}{l}\text { Vitamin E injectable } \\
\text { (aqueous) }\end{array}$ & $\begin{array}{c}\text { Listeria monocytogenes by IP } \\
\text { injection }\end{array}$ & No difference in resistance & Watson \& Petro 1982 [41] \\
\hline $\begin{array}{l}\text { Rats, Sprague-Dawley } \\
\qquad(n=6)\end{array}$ & 3 weeks & $\begin{array}{l}180 \mathrm{mg} / \mathrm{kg} \text { diet + } 6000 \mathrm{IU} \\
\text { vitamin A/ kg diet for } 6 \text { weeks }\end{array}$ & $\begin{array}{l}\text { DL- } \alpha \text {-tocopheryl } \\
\text { acetate }\end{array}$ & $\begin{array}{l}\text { Mycoplasma pulmonis by } \\
\text { aerosol }\end{array}$ & Higher resistance to infection & Tvedten et al. 1973 [42] \\
\hline Lambs $(n=10)$ & NA & $\begin{array}{l}1000 \mathrm{IU} \text { orally, } 300 \mathrm{mg} / \mathrm{kg} \text { diet } \\
\text { for } 23 \text { days }\end{array}$ & $\begin{array}{l}\text { DL- } \alpha \text {-tocopheryl } \\
\text { acetate }\end{array}$ & $\begin{array}{l}\text { Chlamydia by intratracheal } \\
\text { inoculation }\end{array}$ & $\begin{array}{l}\text { Faster recovery (higher food intake and } \\
\text { weight gains) }\end{array}$ & Stephens et al. 1979 [43] \\
\hline
\end{tabular}


Table 3. Cont

\begin{tabular}{|c|c|c|c|c|c|c|}
\hline Subjects & Age & $\begin{array}{c}\text { Dose and Duration of } \\
\text { Supplementation }\end{array}$ & $\begin{array}{c}\text { Form of Vitamin E } \\
\text { Used }\end{array}$ & $\begin{array}{c}\text { Infection Organism and } \\
\text { Route of Infection }\end{array}$ & $\begin{array}{c}\text { Results: Effects of Vitamin E } \\
\text { Supplementation }\end{array}$ & References \\
\hline $\begin{array}{l}\text { Turkey, broadbreasted } \\
\text { white poults }(n=6)\end{array}$ & 1 day & $\begin{array}{l}500 \mathrm{mg} / \mathrm{kg} \text { diet for } 14 \text { days } \\
\text { before infection and } 18-21 \text { days } \\
\text { after infection }\end{array}$ & $\begin{array}{l}\text { DL- } \alpha \text {-tocopheryl } \\
\text { acetate }\end{array}$ & Histomonas meleagridis, oral & $\begin{array}{l}\text { No effect on mortality by vitamin } \mathrm{E} \\
\text { supplementation alone } \\
\text { Lower mortality and lesion score in } \\
\text { combination with ipronidazole }\end{array}$ & Schildknecht \& Squibb 1979 [44] \\
\hline Pigs $(n=6)$ & NA & $\begin{array}{l}200 \mathrm{mg} / \text { pig per day for } 59 \\
\text { days before infection and } 22 \\
\text { days after infection }\end{array}$ & $\begin{array}{l}\text { DL- } \alpha \text {-tocopheryl } \\
\text { acetate }\end{array}$ & Treponema hyodysenteriae, oral & $\begin{array}{c}\text { Improved weight gain and recovery rate } \\
\text { No beneficial effect on appetite and } \\
\text { diarrhoea }\end{array}$ & Teige et al. 1982 [45] \\
\hline Sheep $(n=12)$ & 3-6 months & $\begin{array}{l}300 \mathrm{mg} / \mathrm{kg} \text { diet starting } 2 \\
\text { weeks before first vaccination }\end{array}$ & $\begin{array}{l}\text { DL- } \alpha \text {-tocopheryl } \\
\text { acetate }\end{array}$ & $\begin{array}{l}\text { Clostridium perfringens type D } \\
\text { by IV injection after two IM } \\
\text { vaccinations }\end{array}$ & $\begin{array}{c}\text { Higher Ab titre } \\
\text { Fail to prove beneficial effect of vitamin } \\
\text { E on protection (none of the vaccinated } \\
\text { lambs died) }\end{array}$ & Tengerdy et al. 1983 [46] \\
\hline Cows $(n=20)$ & NA & $\begin{array}{c}740 \mathrm{mg} / \mathrm{cow} \text { per day, duration } \\
\text { NA }\end{array}$ & $\begin{array}{l}\text { DL- } \alpha \text {-tocopheryl } \\
\text { acetate }\end{array}$ & $\begin{array}{l}\text { Natural occurrence of clinical } \\
\text { mastitis due to Streptococci, } \\
\text { Coliform, Staphylococci, } \\
\text { Clostridium bovis }\end{array}$ & Lower clinical cases of mastitis & Smith et al. 1984 [47] \\
\hline $\begin{array}{l}\text { Chicks, broiler } \\
\quad(n=12-14)\end{array}$ & 1day & $\begin{array}{c}150 \mathrm{mg} \text { or } 300 \mathrm{mg} / \mathrm{kg} \text { diet for } 2 \\
\text { weeks before infection }\end{array}$ & $\begin{array}{l}\text { DL- } \alpha \text {-tocopheryl } \\
\text { acetate }\end{array}$ & $\begin{array}{c}\text { Escherichia coli, orally and } \\
\text { post-thoracic air sac }\end{array}$ & $\begin{array}{c}\text { Lower mortality } \\
\text { Higher Ab titre }\end{array}$ & Heinzerling et al. 1974b [48] \\
\hline $\begin{array}{l}\text { Chicks, broiler } \\
\qquad(n=10)\end{array}$ & 1 day & $\begin{array}{l}300 \mathrm{mg} / \mathrm{kg} \text { diet for } 6 \text { weeks, } \\
\text { starting } 3 \text { weeks before first } \\
\text { infection }\end{array}$ & $\begin{array}{l}\text { DL- } \alpha \text {-tocopheryl } \\
\text { acetate }\end{array}$ & E. coli, post-thoracic air sac & Lower mortality & Tengerdy \& Nockels 1975 [49] \\
\hline $\begin{array}{l}\text { Chicks, Leghorn } \\
\quad(n=22)\end{array}$ & 1 day & $\begin{array}{c}300 \mathrm{mg} / \mathrm{kg} \text { diet for } 4 \text { weeks } \\
\text { before infection }\end{array}$ & $\begin{array}{l}\text { DL- } \alpha \text {-tocopheryl } \\
\text { acetate }\end{array}$ & E. coli by IV injection & Lower mortality & Likoff et al. 1981 [50] \\
\hline Pigs $(n=10)$ & 6-8 weeks & $\begin{array}{c}100,000 \mathrm{mg} / \mathrm{t} \mathrm{diet} \mathrm{for} 10 \\
\text { weeks, starting } 2 \text { weeks before } \\
\text { infection }\end{array}$ & $\begin{array}{c}\text { Vitamin E; } \\
\text { Tompson-Hayward, } \\
\text { Minneapolis, MN, } \\
\text { USA }\end{array}$ & E. coli by IM injection & Higher serum Ab titre & Ellis \& Vorhies 1976 [51] \\
\hline
\end{tabular}


Table 4. Effects of vitamin E supplementation on infectious diseases in humans.

\begin{tabular}{|c|c|c|c|c|c|c|}
\hline Subjects & Age & $\begin{array}{l}\text { Dose and Duration of } \\
\text { Supplementation }\end{array}$ & $\begin{array}{c}\text { Form of Vitamin E } \\
\text { Used }\end{array}$ & $\begin{array}{c}\text { Infection Organism and Route } \\
\text { of Infection }\end{array}$ & $\begin{array}{l}\text { Results: Effects of Vitamin E } \\
\text { Supplementation }\end{array}$ & References \\
\hline Male smoker & $50-69$ & $50 \mathrm{mg} / \mathrm{d}$ for median of 6 years & $\begin{array}{l}\text { DL- } \alpha \text {-tocopheryl } \\
\text { acetate }\end{array}$ & Natural incidence of pneumonia & $\begin{array}{c}\text { 69\% Lower incidence of pneumonia } \\
\text { among subgroups including participants } \\
\text { who smoked 5-19 cigarettes per day at } \\
\text { baseline and exercised at leisure time } \\
14 \% \text { Lower incidence of pneumonia } \\
\text { among subgroups including participants } \\
\text { who smoked } \geq 20 \text { cigarettes per day at } \\
\text { baseline and did not exercise }\end{array}$ & Hemila et al. 2016 [52] \\
\hline $\begin{array}{l}\text { HIV-infected } \\
\text { pregnant Tanzanian } \\
\text { women }\end{array}$ & 25.4 & $\begin{array}{c}30 \mathrm{mg} \text { during pregnancy } \\
\text { (multivitamin form with } 20 \mathrm{mg} \\
\text { vitamins B1, } 20 \mathrm{mg} \mathrm{B}, 25 \mathrm{mg} \mathrm{B} 6,100 \\
\text { mg niacin, } 50 \mu \mathrm{g} \mathrm{B12,500} \mathrm{mg} \mathrm{C,} \\
\text { and } 800 \mu \mathrm{g} \text { folic acid) }\end{array}$ & NA & $\begin{array}{l}\text { Natural incidence of malaria } \\
\text { after having received malaria } \\
\text { prophylaxis during pregnancy }\end{array}$ & $\begin{array}{l}\text { Lower incidence of presumptive clinical } \\
\text { malaria, but higher risk of any malaria } \\
\text { parasitemia }\end{array}$ & Olofin et al. 2014 [53] \\
\hline $\begin{array}{c}\text { Patients with } \\
\text { HCV-related cirrhosis }\end{array}$ & $54-75$ & $\begin{array}{l}900 \mathrm{IU} \text { (604.03 mg for D- or } 818.18 \\
\mathrm{mg} \text { for DL-)/day for } 6 \text { months }\end{array}$ & $\alpha$-tocopherol & Natural incidence of cirrhosis & $\begin{array}{c}\text { Reduced glutathione (GSH) and } \\
\text { glutathione peroxidase, which are } \\
\text { significantly lower in cirrhotic patients } \\
(p<0.05) \text {, were comparably improved } \\
\text { by vitamin E regimens }\end{array}$ & Marotta et al. 2007 [54] \\
\hline $\begin{array}{c}\text { Patients with chronic } \\
\text { HCV }\end{array}$ & $18-75$ & 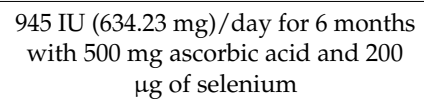 & D- $\alpha$-tocopherol & Natural incidence of $\mathrm{HCV}$ & $\begin{array}{c}\text { No difference in median log plasma } \\
\text { HCV-RNA }\end{array}$ & Groenbak et al. 2006 [55] \\
\hline $\begin{array}{l}\text { Nursing home } \\
\text { residents }\end{array}$ & $>65$ & $200 \mathrm{IU} /$ day for 1 year & DL- $\alpha$-tocopherol & $\begin{array}{c}\text { Natural incidence of respiratory } \\
\text { infections }\end{array}$ & $\begin{array}{l}\text { Fewer numbers of subjects with all and } \\
\text { upper respiratory infections } \\
\text { Lower incidence of common cold } \\
\text { No effect on lower respiratory infection }\end{array}$ & Meydani et al. 2004 [56] \\
\hline Male smokers & $50-69$ & $50 \mathrm{mg} /$ day during 4-year follow-up & $\alpha$-tocopherol & $\begin{array}{l}\text { Natural incidence of common } \\
\text { cold episodes }\end{array}$ & $\begin{array}{l}\text { Lower incidence of common cold } \\
\text { Reduction was greatest among older city } \\
\text { dwellers who smoked fewer than } 15 \\
\text { cigarettes per day }\end{array}$ & Hemila et al. 2002 [57] \\
\hline Male smokers & $50-69$ years & $50 \mathrm{mg} /$ day for median of 6.1 years & $\begin{array}{l}\text { DL- } \alpha \text {-tocopheryl } \\
\text { acetate }\end{array}$ & Natural incidence of pneumonia & $\begin{array}{l}\text { No overall effect on the incidence of } \\
\text { pneumonia. } \\
\text { Lower incidence of pneumonia among } \\
\text { the subjects who had initiated smoking } \\
\text { at a later age }(>21)\end{array}$ & Hemila et al. 2004 [58] \\
\hline $\begin{array}{l}\text { Non-institutionalized } \\
\text { individuals }\end{array}$ & $>60$ years & $200 \mathrm{mg} /$ day for median of 441 days & $\alpha$-tocopherol acetate & $\begin{array}{l}\text { Natural incidence and severity of } \\
\text { self-reported acute respiratory } \\
\text { tract infections }\end{array}$ & $\begin{array}{l}\text { No effect on incidence and severity of } \\
\text { acute respiratory tract infections }\end{array}$ & Graat et al. 2002 [59] \\
\hline
\end{tabular}




\section{Vitamin E and Immune Cells}

The immunomodulatory mechanisms of $\alpha$-tocopherol in immune cells are depicted in Figure 2.

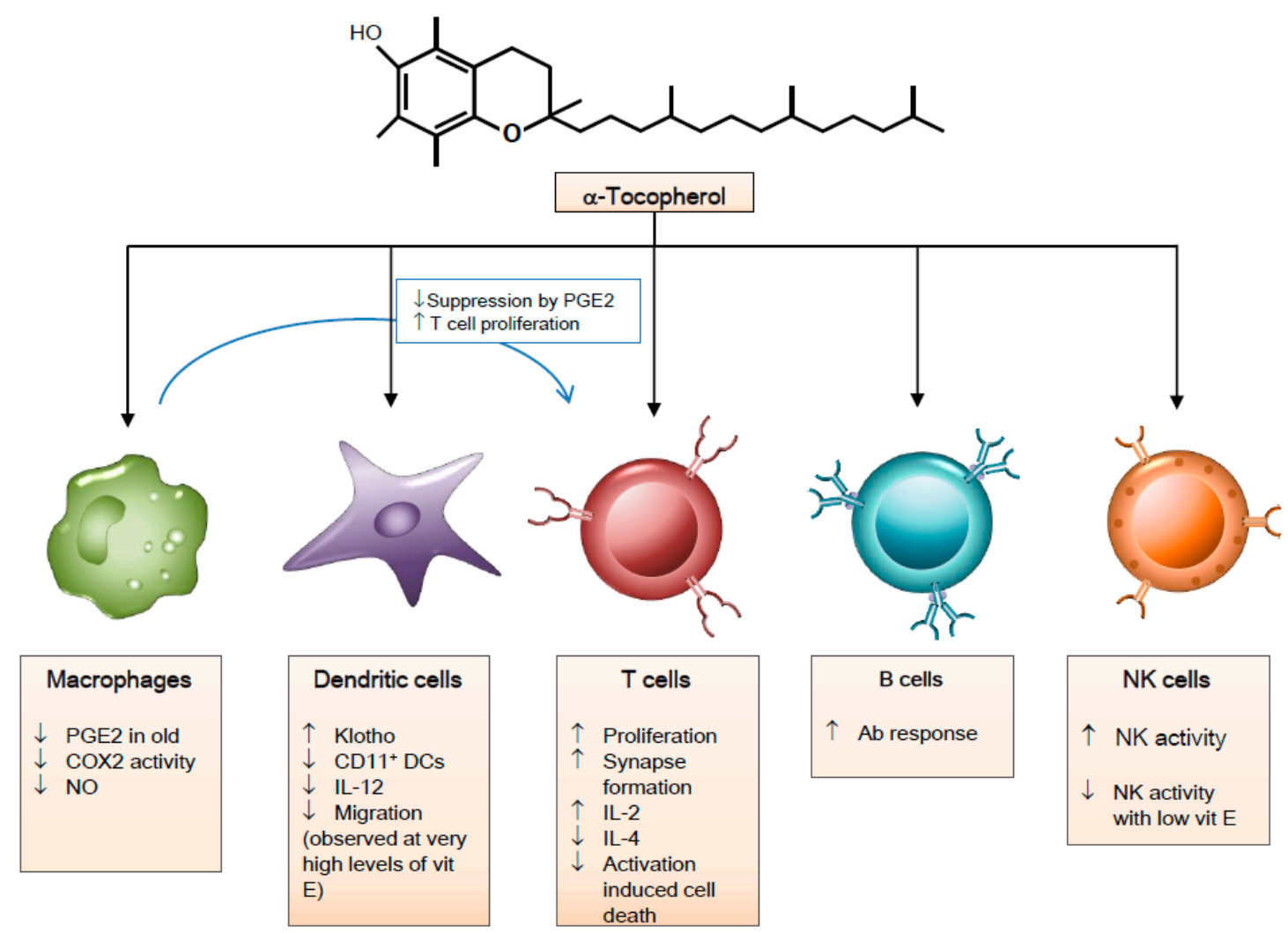

Figure 2. Immunomodulatory effects of vitamin $\mathrm{E}$ on immune cells. Abbreviations: $\mathrm{PGE}_{2}$, prostaglandin $\mathrm{E}_{2} ; \mathrm{COX} 2$, Cyclooxygenase 2; NO, Nitric oxide; CD, Clusters of Differentiation; DCs, Dendritic cells; IL-12, Interleukin-12; Ab, antibody; NK, Natural killer.

\subsection{Macrophages}

Macrophages, important effector cells in the innate immune response, serve as antigen presenting cells (APC) and regulate NK cells and T cells by producing cytokines, reactive oxygen species (ROS), reactive nitrogen species (RNS), and prostaglandins. Cytokines produced by $\mathrm{T}$ cells and other immune cells can shift the macrophages into different populations with distinct physiologies [60].

The effects of vitamin $\mathrm{E}$ on prostaglandin $(\mathrm{PG}) \mathrm{E}_{2}$ production by macrophages from the aged have been suggested as one of the mechanisms by which vitamin E improves the age-associated decrease in the T cell-mediated immune response [61]. In a co-culture experiment in which purified $\mathrm{T}$ cells and macrophages from young and old mice were cultured together, $\mathrm{T}$ cells from young mice showed suppressed proliferation and IL-2 secretion when cultured with macrophages from old mice. When macrophages from old mice were pre-incubated with $10 \mu \mathrm{g} / \mathrm{mL}$ vitamin $\mathrm{E}$ for $4 \mathrm{~h}$, co-cultures of old macrophages and young $\mathrm{T}$ cells showed significant improvement in proliferation. Vitamin $\mathrm{E}$ pre-incubation of old macrophages improved proliferation and IL-2 production in co-cultures of old macrophages and old T cells [62]. Macrophages from old mice produced significantly higher levels of $\mathrm{PGE}_{2}$, which was due to higher cyclooxygenase (COX) activity. Macrophages from old mice expressed higher levels of inducible COX2 protein and mRNA [63]. These increases in $\mathrm{PGE}_{2}$ synthesis and COX activity were lowered by in vivo vitamin E supplementation [64]. Macrophages isolated from old mice fed a diet containing 500 ppm vitamin E for 30 days produced lower amounts of $\mathrm{PGE}_{2}$ and had lower COX activity than those from old mice fed a control diet containing 30 ppm vitamin $\mathrm{E}$, but the COX2 mRNA levels and protein expression of the control and supplemented groups did not 
differ. Thus, vitamin E's effect on COX activity seemed to be through post-translational mechanisms rather than through its effect at transcriptome or translational levels. In a subsequent study, it was shown that vitamin E reduced COX activity in macrophages from old mice by decreasing peroxynitrite production [65]. The inhibition of COX activity by vitamin E in old mice disappeared specifically with the addition of a nitric oxide (NO) donor in the presence of a superoxide to elevate peroxynitrite levels in the macrophage culture. There is a complex interplay between the nitric oxide synthase (NOS) and COX pathways and NO increases COX2 activity, which seems to be due to the NO preventing self-deactivation of COX by the superoxide as NO interacts with the superoxide [66].

In vivo supplementation of vitamin E (1500 IU D- $\alpha$-tocopheryl acetate/day for 16 weeks) in allergic asthmatic patients prevented the suppression of alveolar macrophage nuclear factor (erythroid-derived 2)-like 2 (NRF2) activity after allergen challenge [67]. This study presented the possibility of vitamin E's protective role in allergies and asthmas through regulation of macrophage NRF2 activity, but, further studies are needed to confirm the findings because of the small number of patients (nine mild non-smoking allergic asthmatics) and the lack of appropriate controls.

\subsection{Natural Killer Cells}

NK activity seems to be related with vitamin E status. The NK activity of a boy with Shwachman syndrome who had a severe vitamin E deficiency was low, but improved after eight weeks of $100 \mathrm{mg} / \mathrm{d}$ $\alpha$-tocopherol supplementation. When $\alpha$-tocopherol supplementation was stopped, NK activity and $\mathrm{CD} 6^{+} \mathrm{CD} 6^{+}$cells decreased. $\mathrm{NK}$ activity and $\mathrm{CD} 16^{+} \mathrm{CD} 56^{+}$cells were restored upon resuming eight weeks of $100 \mathrm{mg} / \mathrm{d} \alpha$-tocopherol supplementation [68]. In 37 women aged 90-106 years old, NK cell cytotoxicity was positively associated with plasma vitamin E concentration [69]. A two-week supplementation of $750 \mathrm{mg}$ vitamin $\mathrm{E}$ in colorectal cancer patients resulted in increased NK activity in six out of seven patients. Vitamin E treatment did not result in changes in perforin expression or IFN- $\gamma$ production; therefore, mechanisms of improved NK activity by vitamin E could not be determined from the study [70].

$\mathrm{NO}$ appears to be involved in the impairment of NK cell function. Co-culture of NK cells and myeloid-derived suppressor cells (MDSCs) showed that NK cell cytotoxicity and IFN- $\gamma$ were impaired by MDSCs and that the inhibition of inducible nitric oxide synthase (iNOS) rescued the impairment by MDSCs. Exposure of NK cells to NO by treatment with an NO producer caused the nitration of tyrosine residues on $\mathrm{CD} 16^{+} \mathrm{NK}$ cells. These results suggested that MDSCs impair NK cell function via the production of $\mathrm{NO}$ and the nitration of protein tyrosine residues [71]. Vitamin E might exert its effects on NK cell function by modulating NO levels.

\subsection{Dendritic Cells}

Dendritic cells (DCs) are effective antigen-presenting cells that recognize pathogens and present pathogen-derived antigens to T cells. The interaction of DCs with pathogen-associated molecular patterns (PAMPs) or damage-associated molecular patterns (DAMPs) elicits the activation and maturation of DCs. The increased expression of surface major histocompatibility complex (MHC) molecules and co-stimulatory molecules and the increased production of cytokines occur with the activation of DCs, which allows the effective induction of the T cell response [72-74]. DCs are also involved in tolerance and autoimmunity. DCs might promote tolerance by the generation of Treg cells and/or by the induction of T cell unresponsiveness. DCs might be involved in the pathogenesis of autoimmune disease by promoting the priming or differentiation of self-reactive T cells [72]. Therefore, understanding the regulation of DCs by vitamin E will provide insight into the mechanisms of vitamin E's immune response modulation and implications of vitamin $\mathrm{E}$ in immunological diseases.

Several studies have shown that vitamin E could regulate the maturation and functions of DCs. Tan et al. [75] investigated the effects of $\alpha$-tocopherol and vitamin C, alone or in combination, on the phenotype and functions of human DCs generated from peripheral blood mononuclear cells (PBMCs). During the differentiation of human PBMCs into DCs, various concentrations of $\alpha$-tocopherol 
were treated in culture starting from day 2, cells were stimulated on day 5 , and then the surface phenotype was determined on day 6. The expression of human leukocyte antigen(HLA)-DR, CD40 CD80, and CD86 appeared to be increased with lower concentrations of $\alpha$-tocopherol $(<0.05 \mathrm{mM})$, but the combination of vitamin $\mathrm{E}$ and $\mathrm{C}$ prevented DC activation, as the upregulation of surface markers was not observed. DCs treated with $0.5 \mathrm{mM}$ vitamin $\mathrm{E}$ and $10 \mathrm{mM}$ vitamin $\mathrm{C}$ showed lower levels of intracellular ROS and inhibition of the nuclear factor (NF)- $\mathrm{B}, \mathrm{PKC}$, and p38 mitogen-activated protein kinase (MAPK) pathways. When bone marrow-derived dendritic cells (BMDCs) from Balb/c mice were treated with $500 \mu \mathrm{M}$ of $\alpha$-tocopherol for $2 \mathrm{~h}$, upregulation of phosphorylated inhibitor of $\kappa B$ (I $\mathrm{B}$ ) by lipopolysaccharide (LPS)-stimulation was suppressed. Vitamin E treatment for $24 \mathrm{~h}$ resulted in a reduced number of $\mathrm{CD} 11^{+} \mathrm{CD} 86^{+}$cells and ROS-positive cells, lower production of IL-12p70 and TNF- $\alpha$, and decreased transwell migration of BMDCs. These effects of vitamin E on BMDCs were partly dependent on Klotho expression. Vitamin E treatment on BMDCs resulted in higher Klotho transcript and protein levels, and silencing of Klotho by transfection of Klotho siRNA abolished the inhibitory effects of vitamin E on IL-12p70 production, number of ROS-positive cells, and DC migration [76]. Klotho is a membrane protein that has been shown to mediate calcium transport into the cells; regulate intracellular signaling pathways such as p53/p21, cyclin adenosine monophosphate (cAMP), PKC, and Wnt; and inhibit the NF- $\mathrm{kB}$ pathway [77]. Therefore, the upregulation of Klotho by vitamin $\mathrm{E}$ could be one of the mechanisms by which vitamin $\mathrm{E}$ modulates NF- $\mathrm{KB}$ mediated DC function and maturation. However, the level of $\alpha$-tocopherol used for in vitro treatment $(500 \mu \mathrm{M})$ was high and, therefore, further research is needed to elucidate the physiological relevance of vitamin $\mathrm{E}$ treatment on the expression of Klotho and its involvement in the modulation of DC function.

In vivo supplementation of $\alpha$-tocopherol at 150,250 , and $500 \mathrm{mg} / \mathrm{kg}$ diet in allergic female mice reduced the lung $C D 11 b^{+}$DCs and mRNA levels of IL-4, IL-33, thymic stromal lymphopoietin (TSLP), eotaxin 1 (CCL11), and eotaxin 2 (CCL24) in allergen challenged pups. Furthermore, when BMDCs from 10-day-old neonates born to a control female were treated with $80 \mu \mathrm{M} \alpha$-tocopherol for $24 \mathrm{~h}$, the number of $\mathrm{CD}_{4} 5^{+} \mathrm{CD} 11 \mathrm{~b}^{+} \mathrm{CD} 11^{+} \mathrm{DC}$ and the number of CD45 ${ }^{+} \mathrm{CD} 11 \mathrm{~b}^{+} \mathrm{CD} 11 \mathrm{c}^{+} \mathrm{Ly}_{6 \mathrm{c}}{ }^{-} \mathrm{MHCII}^{-}$ DCs were reduced. Maternal supplementation with $\alpha$-tocopherol was effective in decreasing allergic responses in offspring from allergic mothers by affecting the development of subsets of DCs that are critical for allergic responses [78]. On the other hand, $\gamma$-tocopherol supplementation exerted an opposite response in the same model. In vivo supplementation of $\gamma$-tocopherol at $250 \mathrm{mg} / \mathrm{kg}$ diet in allergic female mice resulted in a higher number of lung eosinophils, a higher number of lung CD11 $\mathrm{c}^{+}$ CD11b ${ }^{+}$DCs, and higher levels of lung lavage CCL11 in the offspring [79].

Modulation of the immune response by vitamin $\mathrm{E}$ has been observed in animal and human studies, and DCs play a critical role in bridging innate and adaptive immune systems and initiating adaptive immune responses. Despite the importance of $\mathrm{DCs}^{\prime}$ role in adaptive immune responses and in diseases such as autoimmune diseases, few studies have investigated the DC-specific effect of vitamin E.

\subsection{T Cells}

The effects of vitamin $\mathrm{E}$ on immune cells have been studied the most with $\mathrm{T}$ cells. The dysregulation of immune function occurs with aging and the most significant changes are observed in T cells. Age-associated changes in T cells include, but are not limited to, (1) defects in T cell receptor (TCR) signal transduction such as a decrease in linker for the activation of T cells (LAT) phosphorylation by zeta chain of T cell receptor associated protein kinase 70 (ZAP-70), (2) decreased intracellular influx of calcium following stimulation, (3) diminished synapse formation, (4) diminished activation of the mitogen activated protein kinase (MAP kinase) pathway, (5) decreased nuclear factor of activated T-cells (NFAT) binding activity, and (6) a shift of the T cell population toward memory T cells [80]. As a result, diminished production of IL-2 and reduced proliferative capacity of naive T cells are observed and impaired $\mathrm{T}$ cell functions contribute to increased susceptibility to infectious diseases and poor response to immunization. 
Vitamin E has been shown to increase the cell division and IL-2 producing capacity of naïve T cells, increase the percentage of $\mathrm{T}$ cells capable of forming an effective immune synapse, and reverse the age-associated defect in the phosphorylation of LAT in T cells from old animals [81-83].

In vitro pre-incubation with $46 \mu \mathrm{M}$ vitamin $\mathrm{E}$ for $4 \mathrm{~h}$ increased proliferation and IL-2 production in $T$ cells purified from old mice stimulated with anti-CD3 and anti-CD28. Increased IL-2 production was due to both an increase in the number of activation-induced IL-2 ${ }^{+}$cells and an increase in the level of IL-2 accumulated per cell. Vitamin E specifically increased the naive T cells' ability to progress through the cell division cycle in old mice [81]. The gene expression profile of $\mathrm{T}$ cells isolated from young and old mice fed a diet supplemented with $500 \mathrm{ppm}$ vitamin $\mathrm{E}$ for four weeks provided evidence that vitamin E influences cell cycle-related molecules at the gene expression level. Higher expression of cell cycle-related genes $C c n b 2, C d c 2$, and $C d c 6$ was observed in stimulated T cells from old mice fed the vitamin E-supplemented diet compared with those fed the control diet, which was not observed in young mice [84]. Cyclin B2, encoded by $C c n b 2$, binds to cyclin-dependent kinase 1 (also known as $\mathrm{Cdc} 2$ ) and regulates the events during both the $\mathrm{G}_{2} / \mathrm{M}$ transition and progression through mitosis. Cdc6 is a key regulator in the early steps of DNA replication, as the binding of Cdc6 to chromatin is a necessary and universal step in the acquisition of replication competences [85]. These alterations in the expression of cell cycle-related genes observed with vitamin E might contribute to vitamin $\mathrm{E}$ improving the proliferative ability of old T cells.

Marko et al. [82] showed that pre-incubation of CD4+ T cells isolated from old T cells with $46 \mu \mathrm{M}$ vitamin $\mathrm{E}$ for $4 \mathrm{~h}$ increased the percentage of $\mathrm{CD} 4^{+} \mathrm{T}$ cells displaying effective immune synapses. Redistribution of Zap70, LAT, Vav, and phospholipase C $\gamma$ (PLC $\gamma$ ) into immune synapse increased significantly with vitamin $\mathrm{E}$ treatment. This change was confirmed with in vivo supplementation of vitamin E. In old mice fed a diet containing $500 \mathrm{ppm}$ vitamin $\mathrm{E}$ for eight weeks, LAT and Vav showed significantly higher redistribution into the T cell/APC contact area when purified CD4 ${ }^{+}$ $\mathrm{T}$ cells were stimulated with murine $\mathrm{CD} 3 \varepsilon$ hybridoma. In a subsequent study, it was shown that vitamin E could reverse the age-associated defect in the phosphorylation of LAT on tyrosine 191 [83]. The phosphorylation of LAT is required for the recruitment of adaptor and effector proteins. Therefore, it plays a pivotal role in the assembly of microcluster structures in the initiation of $\mathrm{T}$ cell activation signals. This evidence suggests that vitamin $\mathrm{E}$ can modulate the early stages of $\mathrm{T}$ cell activation.

Vitamin E seems to modulate Th1 and Th2 responses. The polarization of CD4 T cells to T helper (Th) 1 or Th2 cells has implications for the protection against different pathogens (intracellular vs. extracellular pathogens) and the development of different types of chronic diseases (inflammatory vs. allergic diseases). PBMCs isolated from allergic donors treated with vitamin E (12.5-50 $\mu \mathrm{M})$ showed dose-dependent decreases in IL-4 production [86]. IL-4 mRNA levels in activated PBMCs were downregulated by $25 \mu \mathrm{M}$ vitamin $\mathrm{E}$ treatment. Jurkat $\mathrm{T}$ cells treated with $50 \mu \mathrm{M}$ vitamin $\mathrm{E}$ exhibited downregulation of IL-4 promoter activity, which might be related to vitamin E blocking the interaction of transcription factors with PRE-1 and P1. In vivo supplementation of vitamin E enhancing the Th1 response has been observed in mice infected with influenza virus and in colorectal cancer patients $[6,87]$. In colorectal cancer patients, two weeks of supplementation with $750 \mathrm{mg}$ vitamin $\mathrm{E}$ led to an increased frequency of IL-2 producing CD4+ T cells and increased IFN- $\gamma$ production [87]. In old mice infected with influenza virus, $500 \mathrm{ppm}$ vitamin E supplementation for eight weeks prior to infection lowered the viral titer in the lung, and this protective effect of vitamin E was associated with the enhancement of Th1 response. IFN- $\gamma$ production levels correlated negatively with viral titer, and old mice fed a vitamin E-supplemented diet produced significantly higher levels of IFN- $\gamma$ and IL-2 [6]. The gene expression profile of T cells isolated from young and old mice fed a diet supplemented with $500 \mathrm{ppm}$ vitamin $\mathrm{E}$ for four weeks provided evidence that vitamin $\mathrm{E}$ influences the Th1/Th2 balance at the gene expression level. The increase in IL-4 expression following stimulation was lower in $\mathrm{T}$ cells from old mice fed the vitamin E-supplemented diet compared with those fed the control diet, and the ratio of IFN- $\gamma$ and IL-4 expression levels was significantly higher in the vitamin E group than in the control group [84]. 
Vitamin E can affect activation-induced cell death in T cells. In vitro treatment of primary human T cells with $25 \mu \mathrm{M}$ vitamin E suppressed CD95L expression and activation-induced cell death [88]. The reduction of CD95L mRNA levels and the proportion of CD95L-positive cells were related to the suppression of NF- $\mathrm{BB}$ and AP-1 binding to the CD95L promoter target site by vitamin E. On the other hand, $\alpha$-tocopheryl succinate was shown to trigger apoptosis in Jurkat cells with caspase-activation involved [89].

\subsection{B Cells}

Vitamin E supplementation has been reported to enhance humoral responses. Higher antibody responses have been observed in animals and humans [19,27]. However, it is hard to differentiate whether vitamin E's direct effect on B cells or indirect effect through $\mathrm{T}$ cells contributes to higher antibody responses.

\section{Conclusions}

Vitamin E has been shown to enhance immune responses in animal and human models and to confer protection against several infectious diseases. Suggested mechanisms involved with these changes are (1) the reduction of $\mathrm{PGE}_{2}$ production by the inhibition of COX2 activity mediated through decreasing NO production, (2) the improvement of effective immune synapse formation in naive $\mathrm{T}$ cells and the initiation of T cell activation signals, and (3) the modulation of Th1/Th2 balance. Higher NK activity and changes in dendritic function such as lower IL-12 production and migration were observed with vitamin E, but underlying mechanisms need to be further elucidated

Several considerations are warranted for the advancement in our understanding of vitamin E's role in immunity. For in vitro studies to support implications for the regulation of immunological diseases, the physiological relevance of vitamin E levels used for treatment should be considered. Different forms of vitamin E exert differential effects on immune cells. Cell-specific effects of vitamin E provide valuable evidence regarding the immunomodulatory mechanisms of vitamin $E$, but the interplay between immune cells should not be ignored, because interactions between immune cells are critical in the regulation of immune function.

Author Contributions: Literature search and manuscript preparation were performed by G.Y.L. and S.N.H. The manuscript was revised and finalized by S.N.H.

Funding: This work was supported by the Basic Science Research Program through the National Research Foundation of Korea (NRF) funded by the Ministry of Education (grant number NRF-2018R1D1A1B07049178).

Conflicts of Interest: The author declares no conflicts of interests.

\section{References}

1. Traber, M.G. Vitamin E regulatory mechanisms. Annu. Rev. Nutr. 2007, 27, 347-362. [CrossRef] [PubMed]

2. Sheppard, A.J.; Pennington, J.A.T.; Weihrauch, J.L. Analysis and distribution of vitamin E in vegetable oils and foods. In Vitamin E in Health and Disease; Packer, L., Fuchs, J., Eds.; Marcel Dekker: New York, NY, USA, 1980; pp. 7-65.

3. Traber, M.G.; Atkinson, J. Vitamin E, antioxidant and nothing m more. Free Rad. Biol. Med. 2007, 43, 4-15. [CrossRef] [PubMed]

4. Zingg, J.M. Vitamin E: A role in signal transduction. Annu. Rev. Nutr. 2015, 35, 135-173. [CrossRef] [PubMed]

5. Heinzerling, R.H.; Tengerdy, R.P.; Wick, L.L.; Lueker, D.C. Vitamin E protects mice against Diplococcus pneumoniae type I infection. Infect. Immun. 1974, 10, 1292-1295. [PubMed]

6. Han, S.N.; Wu, D.; Ha, W.K.; Beharka, A.; Smith, D.E.; Bender, B.S.; Meydani, S.N. Vitamin E supplementation increases T helper 1 cytokine production in old mice infected with influenza virus. Immunology 2000, 100, 487-493. [CrossRef] [PubMed]

7. Hayek, M.G.; Taylor, S.F.; Bender, B.S.; Han, S.N.; Meydani, M.; Smith, D.E.; Eghtesada, S.; Meydani, S.N. Vitamin E supplementation decreases lung virus titers in mice infected with influenza. J. Infect. Dis. 1997, 176, 273-276. [CrossRef] [PubMed] 
8. Dalia, A.M.; Loh, T.C.; Sazili, A.Q.; Jahromi, M.F.; Samsudin, A.A. Effects of vitamin E, inorganic selenium, bacterial organic selenium, and their combinations on immunity response in broiler chickens. BMC Vet. Res. 2018, 14, 249. [CrossRef] [PubMed]

9. Wang, L.; Xu, X.; Su, G.; Shi, B.; Shan, A. High concentration of vitamin E supplementation in sow diet during the last week of gestation and lactation affects the immunological variables and antioxidative parameters in piglets. J. Dairy Res. 2017, 84, 8-13. [CrossRef] [PubMed]

10. O'Brien, T.; Thomas, D.G.; Morel, P.C.; Rutherfurd-Markwick, K.J. Moderate dietary supplementation with vitamin E enhances lymphocyte functionality in the adult cat. Res. Vet. Sci. 2015, 99, 63-69. [CrossRef] [PubMed]

11. Ren, Z.; Pae, M.; Dao, M.C.; Smith, D.; Meydani, S.N.; Wu, D. Dietary supplementation with tocotrienols enhances immune function in C57BL/ 6 mice. J. Nutr. 2010, 140, 1335-1341. [CrossRef] [PubMed]

12. Bendich, A.; Gabriel, E.; Machlin, L.J. Dietary vitamin E requirement for optimum immune responses in the rat. J. Nutr. 1986, 116, 675-681. [CrossRef] [PubMed]

13. Meydani, S.N.; Meydani, M.; Verdon, C.P.; Shapiro, A.A.; Blumberg, J.B.; Hayes, K.C. Vitamin E supplementation suppresses prostaglandin E1(2) synthesis and enhances the immune response of aged mice. Mech. Ageing Dev. 1986, 34, 191-201. [CrossRef]

14. Wakikawa, A.; Utsuyama, M.; Wakabayashi, A.; Kitagawa, M.; Hirokawa, K. Vitamin E enhances the immune functions of young but not old mice under restraint stress. Exp. Gerontol. 1999, 34, 853-862. [CrossRef]

15. Moriguchi, S.; Kobayashi, N.; Kishino, Y. High dietary intakes of vitamin E and cellular immune functions in rats. J. Nutr. 1990, 120, 1096-1102. [CrossRef] [PubMed]

16. Sakai, S.; Moriguchi, S. Long-term feeding of high vitamin E diet improves the decreased mitogen response of rat splenic lymphocytes with aging. J. Nutr. Sci. Vitaminol. 1997, 43, 113-122. [CrossRef] [PubMed]

17. Reddy, P.G.; Morrill, J.L.; Minocha, H.C.; Stevenson, J.S. Vitamin E is Immunostimulatory in calves. J. Dairy Sci. 1987, 70, 993-999. [CrossRef]

18. Tanaka, J.; Fujiwara, H.; Torisu, M. Vitamin E and immune response. I. Enhancement of helper T cell activity by dietary supplementation of vitamin $\mathrm{E}$ in mice. Immunology 1979, 38, 727-734. [PubMed]

19. Beharka, A.A.; Han, S.N.; Adolfsson, O.; Wu, D.; Lipman, R.; Smith, D.; Cao, G.; Meydani, M.; Meydani, S.N. Long-term dietary antioxidant supplementation reduces production of selected inflammatory mediators by murine macrophages. Nutr. Res. 2000, 20, 281-296. [CrossRef]

20. Capó, X.; Martorell, M.; Sureda, A.; Riera, J.; Drobnic, F.; Tur, J.A.; Pons, A. Effects of Almond- and Olive Oil-Based Docosahexaenoic- and Vitamin E-Enriched Beverage Dietary Supplementation on Inflammation Associated to Exercise and Age. Nutrients. 2016, 8, 619. [CrossRef] [PubMed]

21. Mahalingam, D.; Radhakrishnan, A.K.; Amom, Z.; Ibrahim, N.; Nesaretnam, K. Effects of supplementation with tocotrienol-rich fraction on immune response to tetanus toxoid immunization in normal healthy volunteers. Eur. J. Clin. Nutr. 2011, 65, 63-69. [CrossRef] [PubMed]

22. Radhakrishnan, A.K.; Lee, A.L.; Wong, P.F.; Kaur, J.; Aung, H.; Nesaretnam, K. Daily supplementation of tocotrienol-rich fraction or alpha-tocopherol did not induce immunomodulatory changes in healthy human volunteers. Br. J. Nutr. 2009, 101, 810-815. [CrossRef] [PubMed]

23. Prasad, J.S. Effect of vitamin E supplementation on leukocyte function. Am. J. Clin. Nutr. 1980, 33, 606-608. [CrossRef] [PubMed]

24. Harman, D.; Miller, R.W. Effect of vitamin E on the immune response to influenza virus vaccine and the incidence of infectious disease in man. Age 1986, 9, 21-23. [CrossRef]

25. Meydani, S.N.; Barklund, M.P.; Liu, S.; Meydani, M.; Miller, R.A.; Cannon, J.G.; Morrow, F.D.; Rocklin, R.; Blumberg, J.B. Vitamin E supplementation enhances cell-mediated immunity in healthy elderly subjects. Am. J. Clin. Nutr. 1990, 52, 557-563. [CrossRef] [PubMed]

26. De Waart, F.G.; Portengen, L.; Doekes, G.; Verwaal, C.J.; Kok, F.J. Effect of 3 months vitamin E supplementation on indices of the cellular and humoral immune response in elderly subjects. Br. J. Nutr. 1997, 78, 761-774. [CrossRef] [PubMed]

27. Meydani, S.N.; Meydani, M.; Blumberg, J.B.; Leka, L.S.; Siber, G.; Loszewski, R.; Thompson, C.; Pedrosa, M.C.; Diamond, R.D.; Stollar, B.D. Vitamin E supplementation and in vivo immune response in healthy elderly subjects. A randomized controlled trial. JAMA 1997, 277, 1380-1386. [CrossRef] [PubMed] 
28. Pallast, E.G.; Schouten, E.G.; de Waart, F.G.; Fonk, H.C.; Doekes, G.; von Blomberg, B.M.; Kok, F.J. Effect of 50- and 100-mg vitamin E supplements on cellular immune function in noninstitutionalized elderly persons. Am. J. Clin. Nutr. 1999, 69, 1273-1281. [CrossRef] [PubMed]

29. Okano, T.; Tamai, H.; Mino, M. Superoxide generation in leukocytes and vitamin E. Int. J. Vitam. Nutr. Res. 1991, 61, 20-26. [PubMed]

30. Richards, G.A.; Theron, A.J.; van Rensburg, C.E.; van Rensburg, A.J.; van der Merwe, C.A.; Kuyl, J.M.; Anderson, R. Investigation of the effects of oral administration of vitamin $\mathrm{E}$ and beta-carotene on the chemiluminescence responses and the frequency of sister chromatid exchanges in circulating leukocytes from cigarette smokers. Am. Rev. Respir. Dis. 1990, 142, 648-654. [CrossRef] [PubMed]

31. Kramer, T.R.; Schoene, N.; Douglass, L.W.; Judd, J.T.; Ballard-Barbash, R.; Taylor, P.R.; Bhagavan, H.N.; Nair, P.P. Increased vitamin E intake restores fish-oil-induced suppressed blastogenesis of mitogen-stimulated T lymphocytes. Am. J. Clin. Nutr. 1991, 54, 896-902. [CrossRef] [PubMed]

32. Wu, D.; Han, S.N.; Meydani, M.; Meydani, S.N. Effect of concomitant consumption of fish oil and vitamin E on T cell mediated function in the elderly: A randomized double-blind trial. J. Am. Coll. Nutr. 2006, 25, 300-306. [CrossRef] [PubMed]

33. Cannon, J.G.; Meydani, S.N.; Fielding, R.A.; Fiatarone, M.A.; Meydani, M.; Farhangmehr, M.; Orencole, S.F.; Blumberg, J.B.; Evans, W.J. Acute phase response in exercise. II. Associations between vitamin E, cytokines, and muscle proteolysis. Am. J. Physiol. 1991, 260, 1235-1240. [CrossRef] [PubMed]

34. Pierpaoli, E.; Orlando, F.; Cirioni, O.; Simonetti, O.; Giacometti, A.; Provinciali, M. Supplementation with tocotrienols from Bixa orellana improves the in vivo efficacy of daptomycin against methicillin-resistant Staphylococcus aureus in a mouse model of infected wound. Phytomedicine 2017, 36, 50-53. [CrossRef] [PubMed]

35. Bou Ghanem, E.N.; Clark, S.; Du, X.; Wu, D.; Camilli, A.; Leong, J.M.; Meydani, S.N. The $\alpha$-tocopherol form of vitamin $\mathrm{E}$ reverses age-associated susceptibility to streptococcus pneumoniae lung infection by modulating pulmonary neutrophil recruitment. J. Immunol. 2015, 194, 1090-1099. [CrossRef] [PubMed]

36. De Wolf, B.M.; Zajac, A.M.; Hoffer, K.A.; Sartini, B.L.; Bowdridge, S.; LaRoith, T.; Petersson, K.H. The effect of vitamin E supplementation on an experimental Haemonchus contortus infection in lambs. Vet. Parasitol. 2014, 205, 140-149. [CrossRef] [PubMed]

37. Sheridan, P.A.; Beck, M.A. The immune response to herpes simplex virus encephalitis in mice is modulated by dietary vitamin E. J. Nutr. 2008, 138, 130-137. [CrossRef] [PubMed]

38. Wang, Y.; Huang, D.S.; Eskelson, C.D.; Watson, R.R. Long-Term Dietary Vitamin E Retards Development of Retrovirus-Induced Disregulation in Cytokine Production. Clin. Immunol. Immunopathol. 1994, 72, 70-75. [CrossRef] [PubMed]

39. Reddy, P.G.; Morrill, J.L.; Minocha, H.C.; Morrill, M.B.; Dayton, A.D.; Frey, R.A. Effect of supplemental vitamin E on the immune system of calves. J. Dairy Sci. 1986, 69, 164-171. [CrossRef]

40. Fang, C.H.; Peck, M.D.; Alexander, J.W.; Babcock, G.F.; Warden, G.D. The effect of free radical scavengers on outcome after infection in burned mice. J. Trauma. 1990, 30, 453-456. [CrossRef] [PubMed]

41. Watson, R.; Petro, T.M. Cellular immune response, corticosteroid levels and resistance to Listeria monocytogenes and murine leukemia in mice fed a high vitamin E diet. N.Y. Acad. Sci. 1982, 393, 205-210. [CrossRef]

42. Tvedten, H.W.; Whitehair, C.K.; Langham, R.F. Influence of vitamins A and E on gnotobiotic and conventionally maintained rats exposed to Mycoplasma pulmonis. J. Am. Vet. Med. Assoc. 1973, 163, 605-612. [PubMed]

43. Stephens, L.C.; McChesney, A.E.; Nockels, C.F. Improved recovery of vitamin E-treated lambs that have been experimentally infected with intratracheal Chlamydia. Br. Vet. J. 1979, 135, 291-293. [CrossRef]

44. Schildknecht, E.G.; Squibb, R.L. The effect of vitamins A, E and K on experimentally induced histomoniasis in turkeys. Parasitology 1979, 78, 19-31. [CrossRef] [PubMed]

45. Teige, J.; Tollersrud, S.; Lund, A.; Larsen, H.J. Swine dysentery: The influence of dietary vitamin E and selenium on the clinical and pathological effects of Treponema hyodysenteriae infection in pigs. Res. Vet. Sci. 1982, 32, 95-100. [PubMed]

46. Tengerdy, R.P.; Meyer, D.L.; Lauerman, L.H.; Lueker, D.C.; Nockels, C.F. Vitamin E-enhanced humoral antibody response to Clostridium perfringens type D in sheep. Br. Vet. J. 1983, 139, 147-152. [CrossRef] 
47. Smith, K.L.; Harrison, J.H.; Hancock, D.D.; Todhunter, D.A.; Conrad, H.R. Effect of vitamin E and selenium supplementation on incidence of clinical mastitis and duration of clinical symptoms. J. Dairy Sci. 1984, 67, 1293-1300. [CrossRef]

48. Heinzerling, R.H.; Nockels, C.F.; Quarles, C.L.; Tengerdy, R.P. Protection of chicks against E.coli infection by dietary supplementation with vitamin E. Proc. Soc. Exp. Biol. Med. 1974, 146, 279-283. [CrossRef] [PubMed]

49. Tengerdy, R.P.; Nockels, C.F. Vitamin E or vitamin A protects chickens against E. coli infection. Poult. Sci. 1975, 54, 1292-1296. [CrossRef] [PubMed]

50. Likoff, R.O.; Guptill, D.R.; Lawrence, L.M.; McKay, C.C.; Mathias, M.M.; Nockels, C.F.; Tengerdy, R.P. Vitamin $\mathrm{E}$ and aspirin depress prostaglandins in protection of chickens against Escherichia coli infection. Am. J. Clin. Nutr. 1981, 34, 245-251. [CrossRef] [PubMed]

51. Ellis, R.P.; Vorhies, M.W. Effect of supplemental dietary vitamin E on the serologic response of swine to an Escherichia coli bacterin. J. Am. Vet. Med. Assoc. 1976, 168, 231-232. [PubMed]

52. Hemilä, H. Vitamin E administration may decrease the incidence of pneumonia in elderly males. Clin. Interv. Aging 2016, 11, 1379-1385. [CrossRef] [PubMed]

53. Olofin, I.O.; Spiegelman, D.; Aboud, S.; Duggan, C.; Danaei, G.; Fawzi, W.W. Supplementation with multivitamins and vitamin A and incidence of malaria among HIV-infected Tanzanian women. J. Acquir. Immune Defic. Syndr. 2014, 67 (Suppl. S4), S173-S178. [CrossRef] [PubMed]

54. Marotta, F.; Yoshida, C.; Barreto, R.; Naito, Y.; Packer, L. Oxidative-inflammatory damage in cirrhosis: Effect of vitamin E and a fermented papaya preparation. J. Gastroenterol. Hepatol. 2007, 22, 697-703. [CrossRef] [PubMed]

55. Groenbaek, K.; Friis, H.; Hansen, M.; Ring-Larsen, H.; Krarup, H.B. The effect of antioxidant supplementation on hepatitis $\mathrm{C}$ viral load, transaminases and oxidative status: A randomized trial among chronic hepatitis $\mathrm{C}$ virus-infected patients. Eur. J. Gastroenterol. Hepatol. 2006, 18, 985-989. [CrossRef] [PubMed]

56. Meydani, S.N.; Leka, L.S.; Fine, B.C.; Dallal, G.E.; Keusch, G.T.; Singh, M.F.; Hamer, D.H. Vitamin E and respiratory tract infections in elderly nursing home residents: A randomized controlled trial. JAMA 2004, 292, 828-836. [CrossRef] [PubMed]

57. Hemilä, H.; Kaprio, J.; Albanes, D.; Heinonen, O.P.; Virtamo, J. Vitamin C, vitamin E, and beta-carotene in relation to common cold incidence in male smokers. Epidemiology 2002, 13, 32-37. [CrossRef] [PubMed]

58. Hemilä, H.; Virtamo, J.; Albanes, D.; Kaprio, J. Vitamin E and beta-carotene supplementation and hospital-treated pneumonia incidence in male smokers. Chest 2004, 125, 557-565. [CrossRef] [PubMed]

59. Graat, J.M.; Schouten, E.G.; Kok, F.J. Effect of daily vitamin E and multivitamin-mineral supplementation on acute respiratory tract infections in elderly persons: A randomized controlled trial. JAMA 2002, 288, 715-721. [CrossRef] [PubMed]

60. Mosser, D.M.; Edwards, J.P. Exploring the full spectrum of macrophage activation. Nat. Rev. Immunol. 2008, 8, 958-969. [CrossRef] [PubMed]

61. Meydani, S.N.; Han, S.N.; Wu, D. Vitamin E and immune response in the aged: Molecular mechanisms and clinical implications. Immunol. Rev. 2005, 205, 269-284. [CrossRef] [PubMed]

62. Beharka, A.A.; We, D.; Han, S.N.; Meydani, S.N. Macrophage prostaglandin production contributes to the age-associated decrease in $\mathrm{T}$ cell function which is reversed by the dietary antioxidant vitamin $\mathrm{E}$. Mech. Age. Dev. 1997, 93, 59-77. [CrossRef]

63. Hayek, M.G.; Mura, C.; Wu, D.; Beharka, A.A.; Han, S.N.; Paulson, K.E.; Hwang, D.; Meydani, S.N. Enhanced expression of inducible cyclooxygenase with age in murine macrophages. J. Immunol. 1997, 159, 2445-2451. [PubMed]

64. Wu, D.; Mura, C.; Beharka, A.A.; Han, S.N.; Paulson, K.E.; Hwang, D.; Meydani, S.N. Age-associated increase in PGE2 synthesis and COX activity in murine macrophages is reversed by vitamin E. Am. J. Physiol. 1998, 275, C661-C668. [CrossRef] [PubMed]

65. Beharka, A.A.; Wu, D.; Serafini, M.; Meydani, S.N. Mechanism of vitamin E inhibition of cyclooxygenase activity in macrophages from old mice: Role of peroxynitrite. Free. Radic. Biol. Med. 2002, 32, 503-511. [CrossRef]

66. Sorokin, A. Nitric Oxide Synthase and Cyclooxygenase Pathways: A Complex Interplay in Cellular Signaling. Curr. Med. Chem. 2016, 23, 2559-2578. [CrossRef] [PubMed] 
67. Dworski, R.; Han, W.; Blackwell, T.S.; Hoskins, A.; Freeman, M.L. Vitamin E prevents NRF2 suppression by allergens in asthmatic alveolar macrophages in vivo. Free Radic. Biol. Med. 2011, 51, 516-521. [CrossRef] [PubMed]

68. Adachi, N.; Migita, M.; Ohta, T.; Higashi, A.; Matsuda, I. Depressed natural killer cell activity due to decreased natural killer cell population in a vitamin E-deficient patient with Shwachman syndrome: Reversible natural killer cell abnormality by alpha-tocopherol supplementation. Eur. J. Pediatr. 1997, 156, 444-448. [CrossRef] [PubMed]

69. Ravaglia, G.; Forti, P.; Maioli, F.; Bastagli, L.; Facchini, A.; Mariani, E.; Savarino, L.; Sassi, S.; Cucinotta, D.; Lenaz, G. Effect of micronutrient status on natural killer cell immune function in healthy free-living subjects aged $\geq 90$ y. Am. J. Clin. Nutr. 2000, 71, 590-598. [CrossRef] [PubMed]

70. Hanson, M.G.; Ozenci, V.; Carlsten, M.C.; Glimelius, B.L.; Frödin, J.E.; Masucci, G.; Malmberg, K.J.; Kiessling, R.V. A short-term dietary supplementation with high doses of vitamin E increases NK cell cytolytic activity in advanced colorectal cancer patients. Cancer Immunol. Immunother. 2007, 56, 973-984. [CrossRef] [PubMed]

71. Stiff, A.; Trikha, P.; Mundy-Bosse, B.; McMichael, E.; Mace, T.A.; Benner, B.; Kendra, K.; Campbell, A.; Gautam, S.; Abood, D.; et al. Nitric Oxide Production by Myeloid-Derived Suppressor Cells Plays a Role in Impairing Fc Receptor-Mediated Natural Killer Cell Function. Clin. Cancer Res. 2018, 24, 1891-1904. [CrossRef] [PubMed]

72. Ganguly, D.; Haak, S.; Sisirak, V.; Reizis, B. The role of dendritic cells in autoimmunity. Nat. Rev. Immunol. 2013, 13, 566-577. [CrossRef] [PubMed]

73. Pearce, E.J.; Everts, B. Dendritic cell metabolism. Nat. Rev. Immunol. 2015, 15, 18-29. [CrossRef] [PubMed]

74. Alloatti, A.; Kotsias, F.; Magalhaes, J.G.; Amigorena, S. Dendritic cell maturation and cross-presentation: Timing matters! Immunol. Rev. 2016, 272, 97-108. [CrossRef] [PubMed]

75. Tan, P.H.; Sagoo, P.; Chan, C.; Yates, J.B.; Campbell, J.; Beutelspacher, S.C.; Foxwell, B.M.; Lombardi, G.; George, A.J. Inhibition of NF-kappa B and oxidative pathways in human dendritic cells by antioxidative vitamins generates regulatory T cells. J. Immunol. 2005, 174, 7633-7644. [CrossRef] [PubMed]

76. Xuan, N.T.; Trang, P.T.; Van Phong, N.; Toan, N.L.; Trung, D.M.; Bac, N.D.; Nguyen, V.L.; Hoang, N.H.; van Hai, N. Klotho sensitive regulation of dendritic cell functions by vitamin E. Biol. Res. 2016, 49, 45. [CrossRef] [PubMed]

77. Buendía, P.; Ramírez, R.; Aljama, P.; Carracedo, J. Klotho Prevents Translocation of NFкB. Vitam. Horm. 2016, 101, 119-150. [PubMed]

78. Abdala-Valencia, H.; Berdnikovs, S.; Soveg, F.W.; Cook-Mills, J.M. $\alpha$-Tocopherol supplementation of allergic female mice inhibits development of CD11c+CD11b+ dendritic cells in utero and allergic inflammation in neonates. Am. J. Physiol. Lung Cell. Mol. Physiol. 2014, 307, L482-L496. [CrossRef] [PubMed]

79. Abdala-Valencia, H.; Soveg, F.; Cook-Mills, J.M. $\gamma$-Tocopherol supplementation of allergic female mice augments development of $\mathrm{CD} 11 \mathrm{c}+\mathrm{CD} 11 \mathrm{~b}+$ dendritic cells in utero and allergic inflammation in neonates. Am. J. Physiol. Lung Cell. Mol. Physiol. 2016, 310, L759-L771. [CrossRef] [PubMed]

80. Molano, A.; Meydani, S.N. Vitamin E, signalosomes and gene expression in T cells. Mol. Aspects. Med. 2012, 33, 55-62. [CrossRef] [PubMed]

81. Adolfsson, O.; Huber, B.T.; Meydani, S.N. Vitamin E-enhanced IL-2 production in old mice: Naive but not memory T cells show increased cell division cycling and IL-2-producing capacity. J. Immunol. 2001, 167, 3809-3817. [CrossRef] [PubMed]

82. Marko, M.G.; Ahmed, T.; Bunnell, S.C.; Wu, D.; Chung, H.; Huber, B.T.; Meydani, S.N. Age-associated decline in effective immune synapse formation of $\mathrm{CD} 4(+) \mathrm{T}$ cells is reversed by vitamin E supplementation. J. Immunol. 2007, 178, 1443-1449. [CrossRef] [PubMed]

83. Marko, M.G.; Pang, H.J.; Ren, Z.; Azzi, A.; Huber, B.T.; Bunnell, S.C.; Meydani, S.N. Vitamin E reverses impaired linker for activation of $\mathrm{T}$ cells activation in T cells from aged C57BL/6 mice. J. Nutr. 2009, 139, 1192-1197. [CrossRef] [PubMed]

84. Han, S.N.; Adolfsson, O.; Lee, C.K.; Prolla, T.A.; Ordovas, J.; Meydani, S.N. Age and vitamin E-induced changes in gene expression profiles of T cells. J. Immunol. 2006, 177, 6052-6061. [CrossRef] [PubMed]

85. Pelizon, C. Down to the origin: Cdc6 protein and the competence to replicate. Trends Cell Biol. 2003, 13, 110-113. [CrossRef] 
86. Li-Weber, M.; Giaisi, M.; Treiber, M.K.; Krammer, P.H. Vitamin E inhibits IL-4 gene expression in peripheral blood T cells. Eur. J. Immunol. 2002, 32, 2401-2408. [CrossRef]

87. Malmberg, K.J.; Lenkei, R.; Petersson, M.; Ohlum, T.; Ichihara, F.; Glimelius, B.; Frödin, J.E.; Masucci, G. A short-term dietary supplementation of high doses of vitamin $\mathrm{E}$ increases $\mathrm{T}$ helper 1 cytokine production in patients with advanced colorectal cancer. Clin. Cancer Res. 2002, 8, 1772-1778. [PubMed]

88. Li-Weber, M.; Weigand, M.A.; Giaisi, M.; Süss, D.; Treiber, M.K.; Baumann, S.; Ritsou, E.; Breitkreutz, R.; Krammer, P.H. Vitamin E inhibits CD95 ligand expression and protects T cells from activation-induced cell death. J. Clin. Invest. 2002, 110, 681-690. [CrossRef] [PubMed]

89. Neuzil, J.; Svensson, I.; Weber, T.; Weber, C.; Brunk, U.T. $\alpha$-tocopheryl succinate-induced apoptosis in Jurkat $\mathrm{T}$ cells involves caspase- 3 activation, and both lysosomal and mitochondrial destabilisation. FEBS Lett. 1999, 445, 295-300. [CrossRef]

(C) 2018 by the authors. Licensee MDPI, Basel, Switzerland. This article is an open access article distributed under the terms and conditions of the Creative Commons Attribution (CC BY) license (http://creativecommons.org/licenses/by/4.0/). 